\title{
Obituary of Professor Dr. Gabr Metwally El-Sayed
}

The Public health community had lost an eminent member who shared a lot of the scientific events and helped in the production of many public health cadres as a principal investigator in community based researches and chairperson of the committee of promotion of Al-Azhar university staff in the field of community and occupational medicine.

He was an active board member of the Egyptian community Medicine Association ((ECMA)), involved in all its scientific activities and held the position of the treasurer for many years.

Spots on his career and scientific life:

-Dr Gabr was graduated from Cairo university school of Medicine MBBCH in 1963

-Was granted MD degree from Al-Azhar University, School of Medicine 1976

-Chairperson of the department of Community Medicine, Al-Azhar University for many years

-Chairperson of the Al-Azhar university committee for promotion of staff in the field of Public Health \& Occupational Medicine

- President of the Egyptian board of Family Medicine

- Principal investigator of research, trainer and examiner in the Military academy

- Board member and treasurer of (ECMA) - Had a lot of public health publications and researches

May God bless the soul of Professor Gabr Metwally and send him to heaven. 